\title{
Goose persistence in fall strongly influences Arctic fox diet, but not reproductive success, in the southern Arctic
}

\author{
Ryan S. McDonald ${ }^{a}$, James D. Roth ${ }^{a}$ \& Frank B. Baldwin ${ }^{b}$ \\ aDepartment of Biological Sciences, University of Manitoba, Winnipeg, Canada; ${ }^{b}$ Manitoba Department of Sustainable Development, \\ Winnipeg, Canada
}

\begin{abstract}
Food availability is the primary limitation for terrestrial Arctic predators, many of which rely on rodents that fluctuate in abundance over a 3-5-year period. During rodent scarcity, predators such as Arctic foxes (Vulpes lagopus) consume alternative prey, such as migratory birds, which are plentiful during summer. In most of the Arctic these birds return south by August, but in northern Manitoba, near the southern edge of the Arctic fox distribution, large numbers of lesser snow geese (Chen caerulescens caerulescens) and Canada geese (Branta canadensis interior) persist into October. This extended availability of geese late into fall may reduce the dependence of Arctic foxes on rodents. We used stable isotope and faecal analyses to reconstruct the Arctic fox fall and winter diet and related the most probable contributions of lemmings, goose eggs and juvenile geese with changes in prey availability and fox reproduction. Geese were a potentially important component of the fall diet for Arctic foxes, especially in years with high goose productivity, but rodents were the main component of the diet in late winter, even though rodents were scarce each summer (2010-2013). Furthermore, rodent density had a greater influence on Arctic fox reproduction, which was correlated with the subsequent winter harvest, than any other variable examined. Although geese were important fall prey for Arctic foxes at the southern edge of their distribution, they did not buffer declines in availability of rodents, which were the primary prey in April when food availability is critical for Arctic fox reproduction.
\end{abstract}

\section{KEYWORDS}

Foraging ecology;

predator-prey interactions; food-web/trophic dynamics; pulsed resources; population dynamics; migratory prey

\section{ABBREVIATIONS}

ANOVA: analysis of variance; HSD: honest significant difference test; MANOVA: multi-variate analysis of variance; SD: standard deviation; SIAR: stable isotope analysis in $\mathrm{R}$ software

\section{Introduction}

The terrestrial Arctic food web is characterized by pronounced annual changes in prey availability, driven primarily by multi-year fluctuations in lemming (Dicrostonyx and Lemmus spp.) abundance that influence the dynamics of several predator populations, including snowy owls (Nyctea scandiaca), long-tailed skuas (Stercorarius longicaudus) and Arctic foxes (Vulpes lagopus) (Macpherson 1969; Angerbjörn et al. 1999; Roth 2002; Gilg et al. 2006). These predators specialize on a small number of prey sources, making them particularly sensitive to changes in prey availability (White 1978). When primary prey are scarce, predators often seek alternative food sources, which can help predators sustain survival and reproductive success through periods of food shortage, and may have cascading effects on other prey species (Holt 1977; Abrams \& Matsuda 1996; Abrams et al. 1998).

Arctic foxes eat primarily lemmings and voles throughout most of their range (Macpherson 1969; Angerbjörn et al. 1999; Roth 2002; Gilg et al. 2003). Changes in rodent availability can have a strong impact on Arctic fox survival and reproductive output (Angerbjörn et al. 1999; Gilg et al. 2006). To overcome periods when rodents are scarce, Arctic foxes use alternative foraging strategies, such as storing eggs (Stickney 1991; Samelius \& Alisauskas 2000; Bêty et al. 2002; Samelius et al. 2007; Careau et al. 2008; Samelius et al. 2011) or foraging for marine resources (Roth 2003; Tarroux et al. 2010; Tarroux et al. 2012). Arctic foxes have been found to take as many as 1570 eggs per fox (Samelius \& Alisauskas 2000) and store more than $80 \%$ of the eggs they collect (Stickney 1991; Samelius \& Alisauskas 2000), which they may use well into the following spring (Samelius et al. 2007). These resources can potentially improve Arctic fox survival and reproductive output, but do not fully compensate for declines in rodent prey (Samelius et al. 2011).

Migratory birds, especially geese, can be an important food source for Arctic foxes in summer, but in the high Arctic their availability is limited because they begin their southern migration by late August (Samelius et al. 2007). In the southern extent of the Arctic fox distribution, however, geese may be a more important component of the Arctic fox diet later in the year due to the availability of both locally produced birds and migrants from more northerly nesting areas, which are abundant throughout fall. The addition and persistence of this alternative prey source in fall may help buffer declines in rodent 
availability and improve Arctic fox reproductive success, which drives Arctic fox population dynamics (Tannerfeldt \& Angerbjörn 1998).

We explored the hypothesis that goose productivity influences Arctic fox reproductive success by testing (1) whether goose productivity influenced Arctic fox den success in the same year and (2) whether consumption of geese in fall influenced Arctic fox reproductive output the following year. We predicted that geese would be an important food source for Arctic foxes during fall near the southern limit of their distribution, especially during years when lemming availability was low. We predicted that goose productivity would increase Arctic fox den success in the same year and that the consumption of geese in fall would increase Arctic fox breeding output in the following year. While previous studies have demonstrated the importance of food availability during the winter and spring on Arctic fox reproductive output (Tannerfeldt \& Angerbjörn 1998), few have looked at the effect of food availability in fall, especially at the southern edge of the Arctic fox distribution where alternative prey are abundant until October.

\section{Methods}

Our study area included tundra habitat south and west of Cape Churchill, Manitoba, on the western Hudson Bay coast $\left(58^{\circ} 45^{\prime} \mathrm{N}, 94^{\circ} 10^{\prime} \mathrm{W}\right)$. Arctic foxes are the primary terrestrial predator in the area and collared lemmings (Dicrostonyx richardsoni) are the most common rodent on the tundra, where Arctic foxes are generally located (Scott \& Hansell 1989; Roth 2002). Large numbers of lesser snow geese (Chen caerulescens caerulescens) and Canada geese (Branta canadensis interior) nest in the area (Cooke et al. 1995; Abraham et al. 2005; Reiter \& Andersen 2011). Snow geese nest in colonies, creating a congregation of food resources for predators (Bantle \& Alisauskas 1998; Samelius \& Alisauskas 2000; Gauthier et al. 2004; Giroux et al. 2012), and the number of nesting lesser snow geese has increased substantially in the study area over the past 50 years (Cooke et al. 1995; Abraham et al. 2005). The nearby La Pérouse Bay colony consists of $>20000$ nesting lesser snow geese and Ross's geese (Chen rossii; Cooke et al. 1995), although colonies farther north can be much larger. For example, Karrak Lake - the largest goose colony in the Queen Maud Gulf Bird Sanctuary, in Nunavut, Canada - can include up to 1000000 nesting pairs of Ross's and lesser snow geese (Samelius et al. 2011). Canada goose nests are more widely distributed in the area and, although the number of nesting Canada geese had declined (Nack \& Andersen 2006), their numbers have stabilized in recent years (Reiter \& Andersen 2011). After hatch, both snow geese and Canada geese move to coastal brood rearing areas in salt or fresh water marshes (Nack \& Andersen 2006). Non-nesting geese either leave the area or congregate near the nesting grounds (Nack \& Andersen 2006). Goose abundance increases in the fall as several species from a variety of locations converge on the coast of Hudson Bay during their southern migration. Hunter recovery records of banded geese indicate presence of lesser snow geese, cackling geese (B. hutchinsii), Ross's geese (B. canadensis interior) and Canada geese ( $B$. canadensis maxima) in the study area throughout September, and Canada geese are known to persist occasionally into October (Craven \& Rusch 1983), with the latest recovery reported 10 November (North American Bird Banding Program 2016; query limited to shot recoveries of normal, wild birds marked with leg bands and released immediately after banding).

We used the production index for Eastern Prairie Population Canada geese (juvenile geese $\mathrm{km}^{-2}$ ), which was calculated annually (1976-2010) using estimates of nest density, mean clutch size, and nest success (proportion of nests with eggs that hatched) from a 732 ha study area $10 \mathrm{~km}$ south of Cape Churchill (Reiter \& Andersen 2011). Goose productivity is primarily influenced by spring temperatures and snow cover (Lindholm et al. 1994; Skinner et al. 1998; Dickey et al. 2008), so we assumed productivity of other goose species nesting in the area (predominantly lesser snow geese) would vary similarly among years.

We estimated lemming densities each summer (June-October) from 2010 to 2013 using two trapping sessions, one shortly after snowmelt and one prior to the first snowfall. Densities on each grid were averaged for the two periods before calculating mean rodent density for the year. We used mark'recapture techniques on two trapping grids $(8 \times 8 ; 15 \mathrm{~m}$ between stakes) and two transects $(300 \mathrm{~m} ; 15 \mathrm{~m}$ between stakes) in preferred habitat of collared lemmings within the study area (Scott \& Hansell 1989; Roth 2002). Sherman live-traps were placed within 5 $\mathrm{m}$ of each stake (two traps per grid-stake, three traps per transect-stake) and baited with peanut butter and oats, with apple and bedding added to protect rodents from dehydration and cold temperatures. We checked traps every 4-6 hours over a continuous 48-hour period (modified from Roth 2002). Captured animals were weighed, marked by hair clipping and released at the site of capture.

We surveyed 93 Arctic fox dens during late winter (April) and summer (June and August), between 2010 and 2013. Arctic fox dens were located on raised beach ridges and characterized by lush vegetation, which made them easy to locate (Roth 2003; Gharajehdaghipour et al. 2016). We used the colour of shed hair in and around burrows to distinguish Arctic fox dens from red fox (Vulpes vulpes) dens in April and June. Red foxes are relatively uncommon on 
the tundra where Arctic foxes den, but appear to have increased their use of this habitat in recent years (Roth unpubl. data). We collected faecal samples from dens in April to reconstruct the winter/spring diet. Faecal samples were found above the snow, indicating they were deposited recently and reflect the fox diet around the time of collection (April). We collected shed hair from dens in June and sampled hair from carcasses collected from local trappers (Friesen et al. 2015) to reconstruct the fall diet. We used the proportion of dens with pups in August as an index of Arctic fox reproductive success. This index reflects both breeding effort (e.g., the number of dens in which breeding was attempted) and pup survival. Successful breeding dens can be distinguished from non-breeding dens by the abundance of scat, tracks, digging and prey remains on the den near the end of the breeding season, just prior to pup dispersal (Macpherson 1969; Roth 2003). Prey remains are particularly abundant and scattered around active breeding dens because adult foxes bring food to their pups for the first few months of their lives. In our study area, dens with failed reproduction lose signs of activity in a short time, as scavengers remove prey remains and weather obscures fresh digging activity (Roth unpubl. data). Because we did not determine litter size, we were unable to consider partial litter mortality. Nonetheless, our index provides a reflection of the population-level reproductive success, which drives the overall population dynamics in the area. We also compared our index of Arctic fox reproductive success to the number of Arctic foxes harvested by fur trappers in Churchill during the subsequent trapping season (NovemberMarch; no harvest data were available for the 1995-96 and 2012-13 trapping seasons).

To analyse the Arctic fox winter/spring diet, we randomly chose one faecal sample per den, dried the samples at $90^{\circ} \mathrm{C}$, separated faecal material from prey remains, rinsed the remains under water, and separated prey items (hair, bones, eggshells, etc.), which we identified to the lowest taxonomic level. In most cases, we were unable to identify rodents to species and so we considered rodents as a single prey category for analysis. We estimated the relative importance of prey items in fox scats according to their frequency of occurrence, which we calculated as the number of occurrences of each prey item divided by the number of scat samples (Ciucci et al. 1996; Klare et al. 2011).

To analyse the Arctic fox fall diet, we used stable isotope analysis of white Arctic fox hair that was grown during the fall moult. Stable isotope analysis is a valuable tool for studying animal diets because the stable isotope ratios of a consumer's tissues reflect the individual's diet (Hobson \& Clark 1992; Angerbjörn et al. 1994; Roth 2002). Stable isotope ratios of hair reflect diet over the period of hair growth. Arctic foxes grow their winter coat between
September and November (Chesemore 1970), so Arctic fox winter hair samples reflected their diet during the fall moult. We measured the stable isotope ratios of carbon and nitrogen $\left(\delta^{13} \mathrm{C}\right.$ and $\delta^{15} \mathrm{~N}$, reflecting ${ }^{13} \mathrm{C} /{ }^{12} \mathrm{C}$ and ${ }^{15} \mathrm{~N} /{ }^{14} \mathrm{~N}$, respectively) in Arctic fox hair and prey tissues. We re-analysed prey samples collected in 1994-97 (Roth 2002), including juvenile goose samples salvaged from dens in August 199497, for both $\delta^{13} \mathrm{C}$ and $\delta^{15} \mathrm{~N}$. Hair samples were washed with soap and water to remove surface oil and debris, rinsed thoroughly, dried at approximately $90^{\circ} \mathrm{C}$, and then homogenized to a powder using scissors. Muscle samples of prey items were freeze-dried and neutral lipids were removed using a Soxhlet apparatus with petroleum ether (Friesen et al. 2015) to eliminate variation in stable isotope ratios due to lipid content (DeNiro \& Epstein 1978; Tieszen et al. 1983). Stable isotope ratios were measured at the Stable Isotopes for Innovative Research Lab at the University of Manitoba and the Chemical Tracers Laboratory, Great Lakes Institute for Environmental Research, at the University of Windsor. Nine samples measured at both laboratories were compared using paired t-tests and values were corrected according to the average difference $(0.557 \%$, range $=0.333-0.969$, for $\delta^{15} \mathrm{~N}$ and $0.065 \%$, range $=0.046-0.627$, for $\delta^{13} \mathrm{C}$ ). We also adjusted $\delta^{13} \mathrm{C}$ values to account for reduced $\delta^{13} \mathrm{C}$ in the atmosphere associated with increased $\mathrm{CO}_{2}$ concentrations over time using the equation in Long et al. (2005).

We used the SIAR mixing model to estimate the relative importance of prey items to the Arctic fox diet (Parnell et al. 2010). The SIAR model uses Markov Chain Monte Carlo methods in a Bayesian approach that considers variation in the stable isotope ratios of prey sources and trophic discrimination (i.e., the difference in stable isotope ratios between a consumer and its food due to the tendency for assimilation to favour the heavier isotope). We corrected for trophic discrimination using species- and tissuespecific trophic discrimination factors (Lecomte et al. 2011) and included six likely prey sources in the model, based on availability in the area and the findings of earlier studies (Macpherson 1969; Careau et al. 2008; Giroux et al. 2012). We did not include adult geese as a separate source from juveniles because most of the goose remains we find at fox dens are juveniles, which are likely more vulnerable than adults, and juveniles are more common than adults by an average of 2.5:1 in August (Baldwin unpubl. data). Furthermore, the stable isotope ratios of juvenile and adult geese are likely similar because they have similar diets. We compared stable isotope ratios of prey items using MANOVA, considering $\delta^{13} \mathrm{C}$ and $\delta^{15} \mathrm{~N}$ as dependent variables. Post-hoc analysis involved separate ANOVA tests for $\delta^{13} \mathrm{C}$ and $\delta^{15} \mathrm{~N}$ and Tukey's HSD. We combined the stable 
isotope values of Canada goose juveniles and lesser snow goose juveniles because they were both isotopically and functionally similar (Gannes et al. 1998; Phillips et al. 2005; Phillips 2012). Our SIAR model used non-informative priors, included 500000 iterations, and excluded the first 50000 iterations (burnin) with a thinning of 15 . From the distribution of solutions, we reported the mode, the most common solution produced by the model, of each diet proportion and the $90 \%$ credible intervals, which reflect the range of feasible solutions (Phillips \& Gregg 2003).

Statistical analysis was done using $\mathrm{R}$ software ( $\mathrm{R}$ Core Development Team 2011). Rodent densities were log-transformed to meet assumptions of normality. We used a MANOVA test to compare $\delta^{13} \mathrm{C}$ and $\delta^{15} \mathrm{~N}$ values of Arctic fox hair across years and post hoc comparisons were made for each element using ANOVAs and Tukey's HSD. We used simple linear regression to compare Arctic fox harvest with reproductive success and to examine the effects of juvenile goose density and rodent density on our indices for juvenile goose consumption, lemming consumption, and Arctic fox reproduction. We used a Pearson's correlation test to compare modal lemming consumption with modal egg consumption.

\section{Results}

Rodent densities were low in all years compared to the peak density (ca. $12 \mathrm{ha}^{-1}$ ) observed in 1994 (Roth 2002). Densities were low in $2010\left(0.35 \mathrm{ha}^{-1}\right.$ $\pm \mathrm{SD}=0.60)$ and $2011\left(0.35 \mathrm{ha}^{-1} \pm \mathrm{SD}=0.35\right)$ and increased slightly in $2012\left(1.74 \mathrm{ha}^{-1} \pm \mathrm{SD}=\right.$ $1.74)$ and $2013\left(1.92 \mathrm{ha}^{-1} \pm \mathrm{SD}=1.50\right)$. Three of the 25 individuals captured from 2010 to 2013 (in 4740 trap-nights) were meadow voles (Microtus pennsylvanicus). Because of the low number of captures, we were unable to compare the availability or catchability of voles and lemmings in our study area, but note that collared lemmings were the only rodent species captured in the area from 1994 to 1997 (Roth 2002).

The proportion of Arctic fox breeding dens that produced pups was strongly related to Arctic fox harvest (Fig. 1; $R^{2}=0.776 ; F_{1,4}=13.8 ; p=0.020$ ), suggesting our index of reproductive success is a good reflection of Arctic fox population dynamics. Canada goose density varied among years, but did not affect Arctic fox reproductive success within the same year (Fig. 2a; $R^{2}=0.010 ; F_{1,3}=0.029 ; p=0.876$ ) or in the following breeding season $\left(R^{2}=0.180, F_{1,4}=\right.$ $0.878, p=0.402$ ). However, rodent density in summer positively affected the proportion of Arctic fox breeding dens that were successful that summer (Fig. 2b; $R^{2}=0.718, F_{1,6}=15.27, p=0.008$ ).

Stable isotope ratios of Arctic fox hair, reflecting diet during the previous fall moult, varied annually

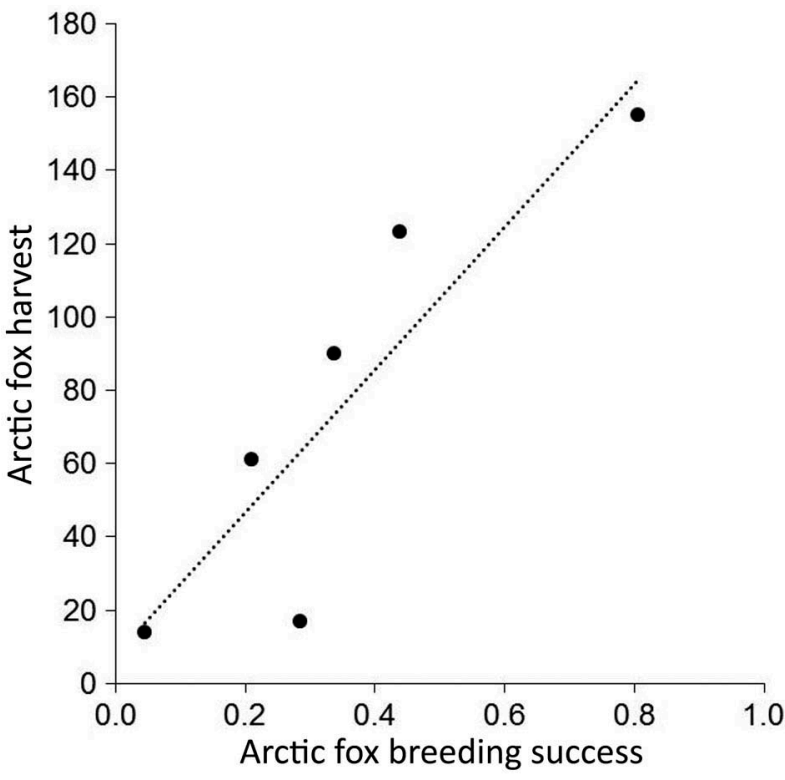

Figure 1. Relationship between Arctic fox harvest and reproductive success (proportion of dens that produced a litter). Harvest data provided by Manitoba Wildlife and Fisheries Branch.

from 1993 to 1996 and 2009 to 2011 (Table 1, Fig. 3; Pillai $\left.=0.460, F_{6,109}=5.43, p<0.001\right)$. Stable isotope ratios of prey differed among species (Table 2). Mixing model results indicated juvenile geese were among the most important fall prey for Arctic foxes in all years, along with lemmings and goose eggs. Caribou (Rangifer tarandus) and willow ptarmigan (Lagopus lagopus) were relatively unimportant (Table 3). The modal contribution of juvenile geese to the fox diet appeared to increase in response to Canada goose productivity (Fig. $4 ; R^{2}=$ $\left.0.620, F_{1,4}=6.66, p=0.061\right)$. The width of the $90 \%$ credible intervals of gosling consumption, reflecting the range of possible solutions, were not influenced by goose productivity $\left(R^{2}=0.391, F_{1,4}=2.56, p=\right.$ $0.184)$ or rodent density $\left(R^{2}=0.099, F_{1,3}=0.331 ; p\right.$ $=0.606)$. Lemming consumption in fall varied but was independent of rodent density $\left(R^{2}=0.201, F_{1,3}\right.$ $=0.755, p=0.449)$. Egg consumption in fall also was unrelated to rodent density $\left(R^{2}=0.125, F_{1,3}=\right.$ $0.429, p=0.560)$ but was negatively related to lemming consumption (Fig. $5 ; R^{2}=0.907, F_{1,5}=$ 49.0, $p=0.001$ ). Arctic fox reproductive success was unrelated to consumption of juvenile geese in the previous fall $\left(R^{2}=0.288, F_{1,5}=2.02, p=0.214\right)$.

Rodents were the most frequent prey item in Arctic fox scats collected in late winter (Fig. 6), despite rodent densities being low during summer trapping sessions from 2010 to 2012. We found eggshell fragments in 30\% of the faecal samples in 2011 and $29 \%$ of the faecal samples in 2012. Feathers were present in $20 \%$ of the samples in 2011 and 14\% of the samples in 2012. Caribou hair was present in four samples in 2011 and one sample in 2012. 

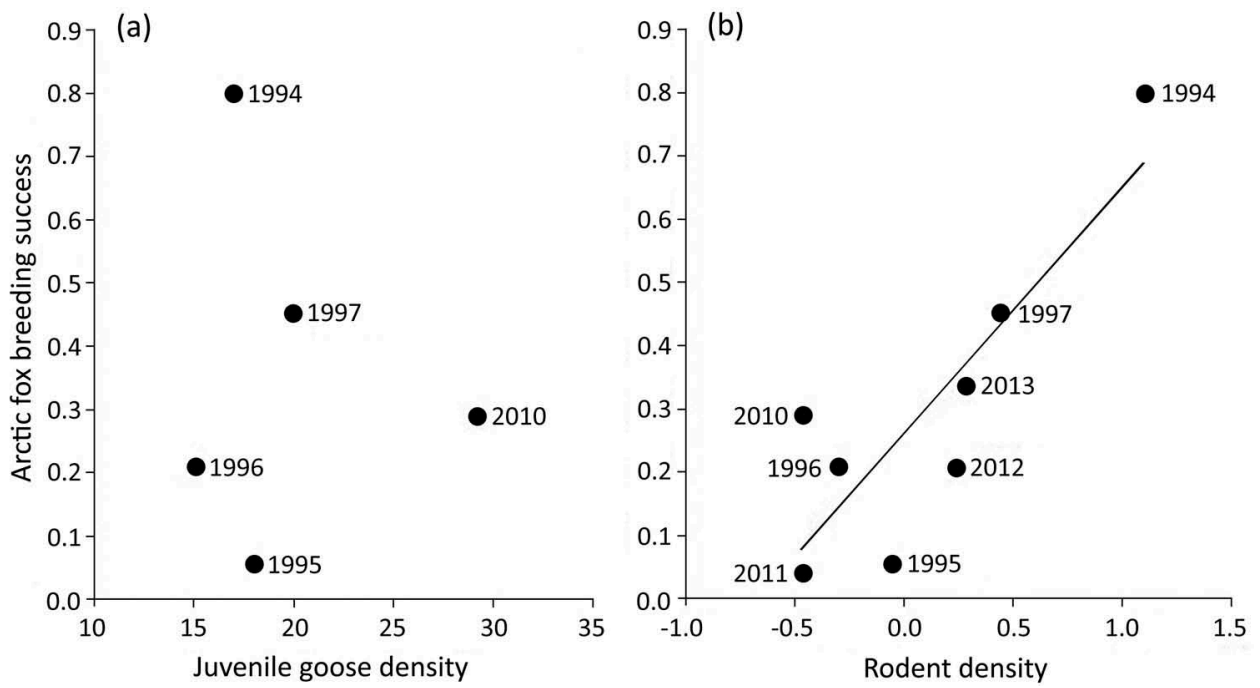

Figure 2. Relationship between Arctic fox reproductive success (proportion of dens that produced a litter) and density of (a) juvenile Canada geese $\left(\mathrm{km}^{-2}\right.$ ) and (b) rodents (log-transformed ha ${ }^{-1}$ ) the same year near Cape Churchill, Manitoba. Reproductive success was unrelated to juvenile goose density, but was positively related to rodent density $\left(R^{2}=0.718\right)$. Arctic fox breeding success reflects the proportion of dens that produced pups. Fox and rodent data for 1994-97 were from Roth (2002, 2003).

Table 1. The stable isotope ratios (mean \pm SE) of Arctic fox hair grown in fall 1993-96 and 2009-2011. Carbon values from 1993-96 were adjusted to reflect atmospheric carbon in 2010 (Long et al. 2005). Years connected by the same letter did not differ (Tukey-Kramer HSD).

\begin{tabular}{lrllllll}
\hline Year (sample size) & \multicolumn{6}{c}{$\delta^{13} \mathrm{C}$} & \multicolumn{5}{c}{$\delta^{15} \mathrm{~N}$} \\
\hline $1993(10)$ & $-23.38 \pm 0.28$ & A & B & $7.66 \pm 0.39$ & A & B & C \\
$1994(11)$ & $-23.67 \pm 0.22$ & & B & $6.61 \pm 0.35$ & & B & C \\
$1995(6)$ & $-22.32 \pm 0.36$ & A & B & $8.71 \pm 0.34$ & A & B & \\
$1996(13)$ & $-22.87 \pm 0.23$ & A & B & $8.19 \pm 0.24$ & A & B & \\
$2009(21)$ & $-22.30 \pm 0.32$ & A & & $8.04 \pm 0.39$ & A & B & \\
$2010(34)$ & $-23.57 \pm 0.09$ & & B & $6.27 \pm 0.23$ & & & C \\
$2011(21)$ & $-22.55 \pm 0.25$ & A & & $8.72 \pm 0.31$ & A & & \\
\hline
\end{tabular}

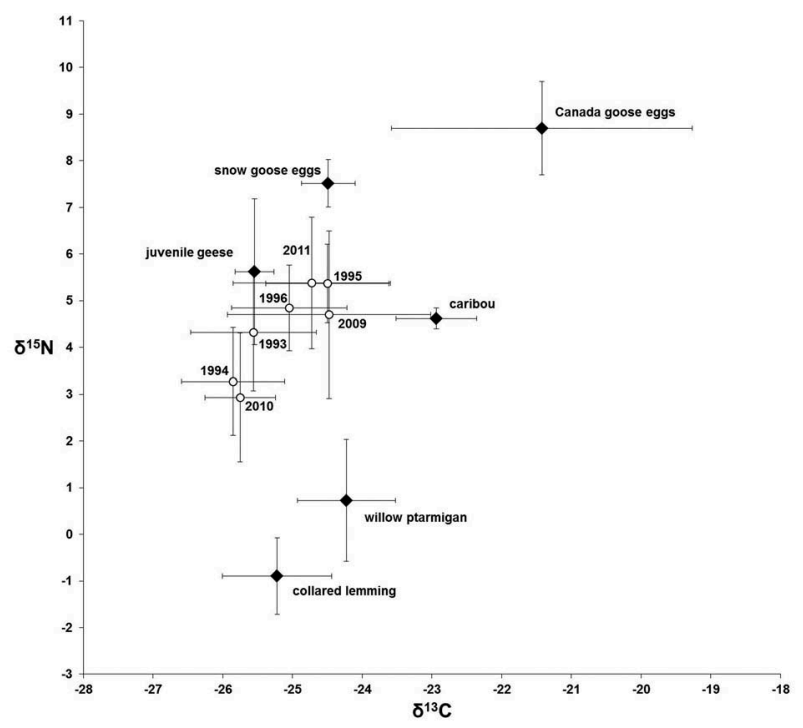

Figure 3. Mean $( \pm S D)$ stable isotope ratios of Arctic fox winter hair (open circles) and prey samples (filled diamonds) in northern Manitoba. Fox hair values were corrected for trophic discrimination (Lecomte et al. 2011). Samples from 1994-97 (Roth 2002) were adjusted for the temporal change in atmospheric carbon to reflect projected values in 2010 (Long et al. 2005).

\section{Discussion}

Our results indicate that geese provide a potential alternative food source in fall for Arctic foxes near the southern extent of the Arctic fox distribution. In the High Arctic, geese migrate south during August (Samelius et al. 2007), but in the southern Arctic, geese are regularly available into October, providing a consistent alternative prey for Arctic foxes into fall. Our results highlight the importance of juvenile geese as a fall food source for Arctic foxes in northern Manitoba. We demonstrated that juvenile geese were one of the primary fall food sources for Arctic foxes, depending on goose productivity. The availability of this alternative food source, however, did not appear to influence Arctic fox reproductive success, although it may help juvenile foxes survive for some time after they disperse from their natal dens. The failure of Arctic foxes to respond numerically to the dramatic increases in nesting goose abundance in the study area over the last 50 years likewise suggests that geese do not provide a sufficient resource to stimulate fox reproduction when lemming densities are low (Roth 2002).

In some areas, Arctic foxes prefer nesting birds and their eggs during the nesting season (Bantle \& Alisauskas 1998) and foxes are more likely to breed in areas with high densities of nesting geese (Giroux et al. 2012). Careau et al. (2008) found that Arctic foxes collected more eggs when lemming densities were low, although they stored similar numbers of eggs in all years, regardless of lemming density. Stored eggs can serve as an important food resource throughout the winter (Samelius \& Alisauskas 2000; Samelius et al. 2007; Careau et al. 2008), when food 
Table 2. Stable isotope ratios (mean $\pm \mathrm{SE}$ ) and mean C:N concentrations in samples of Arctic fox prey (eggs or muscle tissue) collected near Cape Churchill, Manitoba, Canada. Signatures varied among sources (MANOVA, Pillai $=1.534, F_{12,7} 0=19.183, p<$ $0.001)$. Sources connected by the same letter had similar stable isotope ratios $(p>0.05)$, based on post-hoc tests for $\delta^{13} C$ and $\delta^{15} \mathrm{~N}$ that included ANOVA and Tukey's HSD.

\begin{tabular}{|c|c|c|c|c|c|c|c|c|c|}
\hline Source (sample size) & $\mathrm{C}: \mathrm{N}$ & & & & & $5^{15} \mathrm{~N}$ & & & \\
\hline Canada goose egg (10) & 3.37 & $-20.82 \pm 0.68$ & A & & $8.70 \pm 0.32$ & A & & & \\
\hline Canada goose juvenile (4) & 3.06 & $-24.98 \pm 0.10$ & & $B$ & $5.11 \pm 0.23$ & & B & & \\
\hline Caribou (2) & 3.09 & $-22.34 \pm 0.58$ & A & B & $4.62 \pm 0.23$ & & B & & \\
\hline Lemming (10) & 3.21 & $-24.62 \pm 0.10$ & & B & $-0.89 \pm 0.21$ & & & $\mathrm{C}$ & \\
\hline Willow ptarmigan (2) & 3.06 & $-23.62 \pm 0.50$ & & B & $0.73 \pm 0.92$ & & & $\mathrm{C}$ & \\
\hline Snow goose egg (11) & 3.45 & $-23.89 \pm 0.11$ & & $B$ & $7.51 \pm 0.15$ & $A$ & & & D \\
\hline Snow goose juvenile (3) & 3.21 & $-24.91 \pm 0.24$ & & B & $6.30 \pm 1.39$ & & B & & D \\
\hline
\end{tabular}

Table 3. The most likely relative contribution (mode) of prey sources to the Arctic fox fall diet estimated by the stable isotopemixing model SIAR (Parnell et al. 2010). Values in parenthesis represent $90 \%$ credible intervals.

\begin{tabular}{|c|c|c|c|c|c|c|c|}
\hline & 1993 & 1994 & 1995 & 1996 & 2009 & 2010 & 2011 \\
\hline Collared lemming & $\begin{array}{c}25 \\
(12-38)\end{array}$ & $\begin{array}{c}38 \\
(25-50)\end{array}$ & $\begin{array}{c}14 \\
(0-25)\end{array}$ & $\begin{array}{c}19 \\
(8-30)\end{array}$ & $\begin{array}{c}21 \\
(7-33)\end{array}$ & $\begin{array}{c}40 \\
(33-48)\end{array}$ & $\begin{array}{c}11 \\
(1-23)\end{array}$ \\
\hline Snow goose egg & $\begin{array}{c}21 \\
(0-37)\end{array}$ & $\begin{array}{c}3 \\
(0-29)\end{array}$ & $\begin{array}{c}20 \\
(1-35)\end{array}$ & $\begin{array}{c}22 \\
(1-39)\end{array}$ & $\begin{array}{c}22 \\
(1-37)\end{array}$ & $\begin{array}{c}1 \\
(0-8)\end{array}$ & $\begin{array}{c}28 \\
(1-46)\end{array}$ \\
\hline Canada goose egg & $\begin{array}{c}1 \\
(0-17)\end{array}$ & $\begin{array}{c}1 \\
(0-11)\end{array}$ & $\begin{array}{c}20 \\
(1-31)\end{array}$ & $\begin{array}{c}2 \\
(0-22)\end{array}$ & $\begin{array}{c}2 \\
(0-23)\end{array}$ & $\begin{array}{c}0 \\
(0-2)\end{array}$ & $\begin{array}{c}2 \\
(0-18)\end{array}$ \\
\hline Juvenile geese & $\begin{array}{c}27 \\
(5-55)\end{array}$ & $\begin{array}{c}37 \\
(10-58)\end{array}$ & $\begin{array}{c}22 \\
(1-37)\end{array}$ & $\begin{array}{c}26 \\
(8-49)\end{array}$ & $\begin{array}{c}24 \\
(4-43)\end{array}$ & $\begin{array}{c}54 \\
(43-63)\end{array}$ & $\begin{array}{c}32 \\
(12-67)\end{array}$ \\
\hline Caribou & $\begin{array}{c}2 \\
(0-23)\end{array}$ & $\begin{array}{c}1 \\
(0-16)\end{array}$ & $\begin{array}{c}9 \\
(0-30)\end{array}$ & $\begin{array}{c}2 \\
(0-24)\end{array}$ & $\begin{array}{c}2 \\
(0-26)\end{array}$ & $\begin{array}{c}0 \\
(0-3)\end{array}$ & $\begin{array}{c}2 \\
(0-20)\end{array}$ \\
\hline Willow ptarmigan & $\begin{array}{c}2 \\
(0-27)\end{array}$ & $\begin{array}{c}1 \\
(0-19)\end{array}$ & $\begin{array}{c}16 \\
(0-32)\end{array}$ & $\begin{array}{c}3 \\
(0-29)\end{array}$ & $\begin{array}{c}5 \\
(0-30)\end{array}$ & $\begin{array}{c}0 \\
(0-4)\end{array}$ & $\begin{array}{c}2 \\
(0-26)\end{array}$ \\
\hline
\end{tabular}
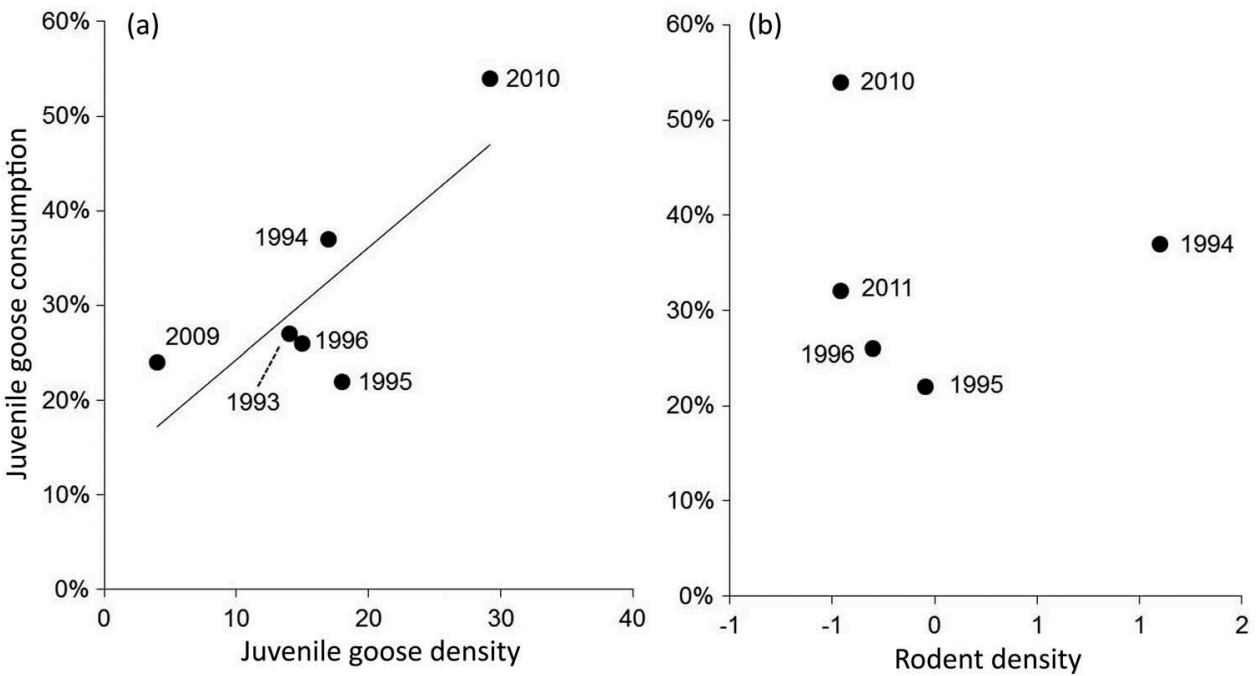

Figure 4. The proportion of juvenile geese in the Arctic fox diet was affected by that year's density of (a) juvenile geese (km ${ }^{-1}$; $R^{2}=0.620$ ), but not (b) lemmings (log-transformed ha ${ }^{-1}$ ). Diet contributions reflect the modal diet estimate from SIAR output.

availability is critical for reproduction (Angerbjörn et al. 1991; Tannerfeldt \& Angerbjörn 1998). Eggs are likely collected by adult foxes because pups do not leave their natal dens during the nesting season and depend on their parents for food. Therefore, in the fall and winter, juvenile foxes might not have access to eggs collected and stored by adults.

Throughout most of their range, Arctic foxes feed primarily on lemming prey, and variation in lemming abundance has been shown to drive Arctic fox population dynamics (Macpherson 1969; Angerbjörn et al.
1999; Roth 2002; Gilg et al. 2003). We found that lemmings were the primary prey of Arctic foxes in April, even though lemming densities in our study area were low between April 2011 and April 2012. Eggshell fragments were found in only $30 \%$ of scat samples in April. Unidentified birds were the third most common prey source followed by caribou. Likely bird prey in the area during winter includes willow ptarmigan or stored prey from the previous fall (e.g., geese). We found no evidence of marine foods in Arctic fox faecal samples collected from fox 


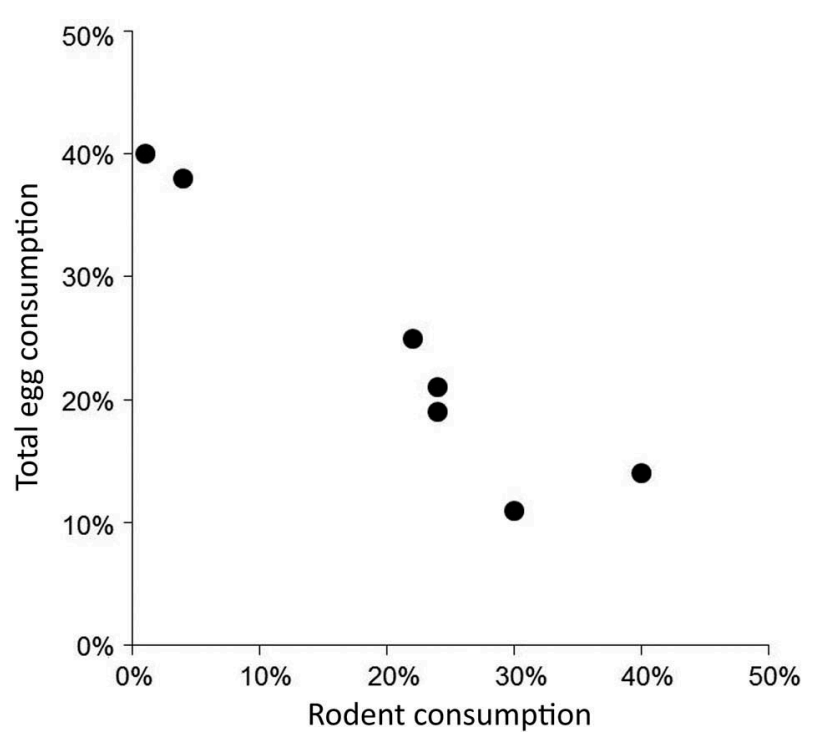

Figure 5. Relationship between rodent consumption and goose egg consumption by Arctic foxes in the fall of 1993-96 and 2009-2011 in northern Manitoba $\left(R^{2}=0.907\right)$. Consumption estimates are the modal diet proportions determined by SIAR (Parnell et al. 2010). The estimated contributions of Canada goose eggs and snow goose eggs were added together to estimate total egg consumption.

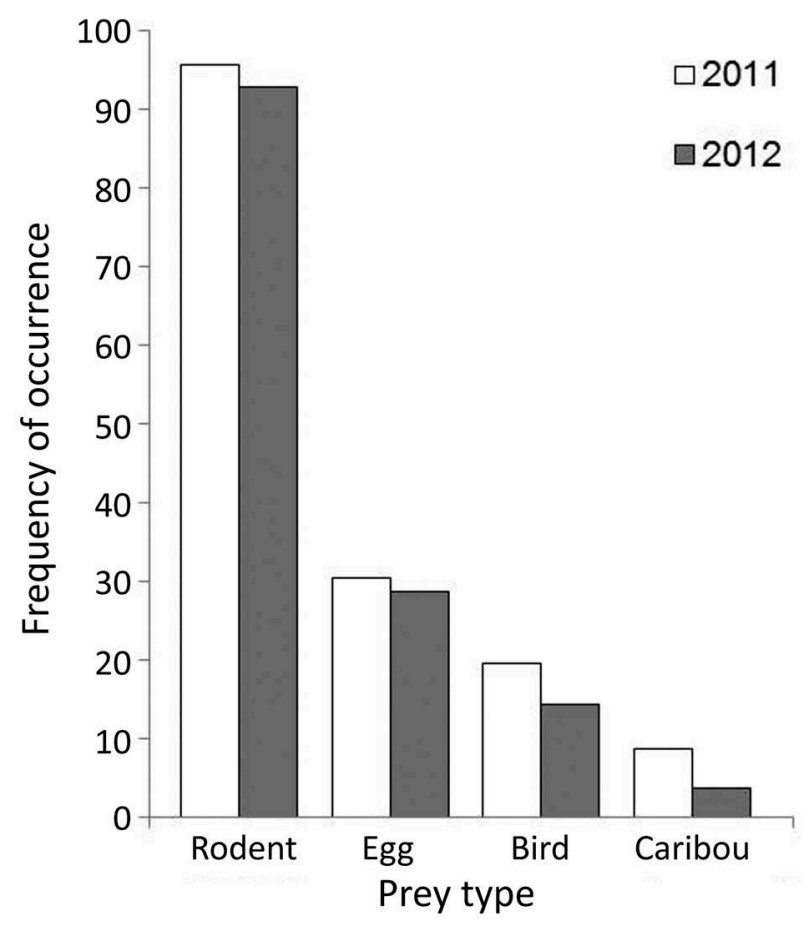

Figure 6. Winter diet of Arctic foxes in northern Manitoba estimated from scat samples collected from dens in April 2011 ( $n=46)$ and $2012(n=28)$. Frequency of occurrence reflects the frequency of each prey type calculated by dividing the number of occurrences of a prey type by the number of faecal samples analysed in each year.

dens in April, but marine prey may be more easily digested, leaving behind little or no traces (e.g., hair or bone) in predator scat. Our samples may have also been biased towards foxes that remained in the breeding area and excluded nomadic foxes that left the breeding area to forage on the sea ice (Tarroux et al. 2010). Studies have shown that marine food sources are important for Arctic foxes during winter (Roth 2003; Tarroux et al. 2010; Tarroux et al. 2012).

Rodent availability, particularly during winter, appears to be the primary influence on Arctic fox reproduction in northern Manitoba, based on our finding that lemmings are the primary prey of Arctic foxes in winter and that Arctic fox reproduction relates to lemming availability. The link between rodent availability and Arctic fox reproduction is similar to other areas where Arctic foxes and lemmings share tightly linked population cycles (Angerbjörn et al. 1999). In our study, rodent availability affected the proportion of Arctic fox dens that produced pups that year, indicating that rodent abundance is a key influence on fox reproductive success. We did not observe large fluctuations in rodent densities between 2010 and 2013, which were consistently much lower than the peak density observed in 1994 (Roth 2002). The last lemming peak on record in the Churchill area was in 2003 (Reiter \& Andersen 2008, 2011), but we found no record of lemming abundance from 2005 to 2009. During periods of low lemming densities, Arctic foxes increase predation on nesting geese and shorebirds (Bêty et al. 2002; Meltofte et al. 2007) and reduce nesting success (Nolet et al. 2013). If rodent densities remain low, Arctic foxes may feed more on eggs and other alternative prey sources. However, because Arctic foxes rely more on lemmings during the late winter and show a stronger numerical response to lemming availability, Arctic foxes near Cape Churchill, Manitoba will likely experience lower reproductive output and overall abundance if lemming densities remain low.

\section{Conclusion}

Our findings highlight seasonal changes in the Arctic fox diet, suggesting that southern Arctic foxes feed heavily on juvenile geese during fall, either before they begin their southern migration or possibly during the southern migration of geese that nest farther north but stage in the Cape Churchill area (Abraham et al. 2005). In the northern Arctic, these food sources are not readily available in the fall, but they appear to be an important food source for Arctic foxes in the southern Arctic. Despite the importance of geese, rodents appear to drive southern Arctic fox population dynamics, as the large litters and low adult survival of Arctic foxes create a rapid population response to annual changes in food availability (Tannerfeldt \& Angerbjörn 1998; Angerbjörn et al. 1999). Although the warming climate could prolong persistence of geese in the southern Arctic into the 
fall, our results suggest this alternative food source would not mitigate the impact of an accompanying decline in lemmings on Arctic fox populations. These changes highlight the broader role of climate change in affecting prey availability, species interactions and Arctic food-web dynamics.

\section{Acknowledgements}

We would like to thank Jill Larkin, Natalie Asselin and Dave Allcorn for their data collection efforts; the Churchill Northern Studies Centre staff (especially LeeAnn Fishback and Michael Goodyear) for logistical support; Olwyn Friesen and Marci Trana for field assistance and comments on previous versions of this manuscript; and S. Armbruster, M. Hanzel, G. Ball, C. Stansbury and I. Burron for field assistance. Additional logistical support was provided by Manitoba Conservation and Parks Canada.

\section{Disclosure statement}

No potential conflict of interest was reported by the authors.

\section{Funding}

This work was supported by the Natural Sciences and Engineering Research Council of Canada; Manitoba Conservation; Parks Canada; the Churchill Northern Studies Centre Northern Research Fund; the University of Manitoba Field Work Support Program.

\section{References}

Abraham K.F., Jefferies R.L. \& Rockwell R.F. 2005. Gooseinduced changes in vegetation and land cover between 1976 and 1997 in an Arctic coastal marsh. Arctic, Antarctic, and Alpine Research 37, 269-275.

Abrams P.A., Holt R.D. \& Roth J.D. 1998. Apparent competition or apparent mutualism? Shared predation when populations cycle. Ecology 79, 201-212.

Abrams P.A. \& Matsuda H. 1996. Positive indirect effects between prey species that share predators. Ecology 77, 610-616.

Angerbjörn A., Arvidson B., Norén E. \& Strömgren L. 1991. The effect of winter food on reproduction in the Arctic fox, Alopex lagopus: a field experiment. Journal of Animal Ecology 60, 705-714.

Angerbjörn A., Hersteinsson P., Lidén K. \& Nelson E. 1994. Dietary variation in Arctic foxes (Alopex lagopus) - an analysis of stable carbon isotopes. Oecologia 99, 226-232.

Angerbjörn A., Tannerfeldt M. \& Erlinge S. 1999. Predator-prey relationships: arctic foxes and lemmings. Journal of Animal Ecology 68, 34-49.

Bantle J.L. \& Alisauskas R.T. 1998. Spatial and temporal patterns in Arctic fox diets at a large goose colony. Arctic 51, 231-236.

Bêty J., Gauthier G., Korpimäki E. \& Giroux J.F. 2002. Shared predators and indirect trophic interactions: lemming cycles and Arctic-nesting geese. Journal of Animal Ecology 71, 88-98.

Careau V., Lecomte N., Bêty J., Giroux J.F., Gautier G. \& Berteaux D. 2008. Hoarding of pulsed resources: temporal variations in egg-caching by Arctic fox. Ecoscience 15, 268-276.

Chesemore D.L. 1970. Notes on the pelage and priming sequence of Arctic foxes in northern Alaska. Journal of Mammalogy 51, 156-159.

Ciucci P., Boitani L., Pelliccioni E.R., Rocco M. \& Guy I. 1996. A comparison of scat-analysis methods to assess the diet of the wolf Canis lupus. Wildlife Biology 2, 37-48.

Cooke R., Rockwell R.F. \& Lank D.B. 1995. The snow geese of La Perouse Bay: natural selection in the wild. Oxford: Oxford University Press.

Craven S.R. \& Rusch D.H. 1983. Winter distribution and affinities of Canada geese marked on Hudson and James Bays. The Journal of Wildlife Management 47, 307-319.

DeNiro M. \& Epstein S. 1978. Influence of diet on the distribution of carbon isotopes in animals. Geochimica et Cosmochimica Acta 42, 495-502.

Dickey M.-H., Gauthier G. \& Cadieux M.-C. 2008. Climate effects on the breeding phenology and reproductive success of an Arctic goose species. Global Change Biology 14, 1973-1985.

Friesen O., Roth J.D. \& Graham L.C. 2015. Sex-biased parasitism in monogamous Arctic foxes is driven by diet. Journal of Mammalogy 96, 417-424.

Gannes L.Z., Martìnez del Rio C. \& Koch P. 1998. Natural abundance variations in stable isotopes and their potential uses in animal physiological ecology. Comparative Biochemistry and Physiology A 119, 725-737.

Gauthier G., Bêty J., Giroux J.-F. \& Rochefort L. 2004. Trophic interactions in a High Arctic snow goose colony. Integrative and Comparative Biology 44, 119-129.

Gharajehdaghipour T., Roth J.D., Fafard P.M. \& Markham J.H. 2016. Arctic foxes as ecosystem engineers: increased soil nutrients lead to increased plant productivity on fox dens. Scientific Reports 6, 24020.

Gilg O., Hanski I. \& Sittler B. 2003. Cyclic dynamics in a simple vertebrate predator-prey community. Science 302, 866-868.

Gilg O., Sittler B., Sabard B., Hurstel A., Sané R., Delattre P. \& Hanski L. 2006. Functional and numerical responses of four lemming predators in High Arctic Greenland. Oikos 113, 196-216.

Giroux M.-A., Berteaux D., Lecomte N., Gauthier G.S. \& Bêty J. 2012. Benefiting from a migratory prey: spatiotemporal patterns in allochthonous subsidization of an Arctic predator. Journal of Animal Ecology 81, 533542.

Hobson K.A. \& Clark R.G. 1992. Assessing avian diets using stable isotopes I: turnover of ${ }^{13} \mathrm{C}$ in tissues. Condor 94, 181-188.

Holt R.D. 1977. Predation, apparent competition, and the structure of prey communities. Theoretical Population Biology 12, 197-229.

Klare U., Kamler J.F. \& MacDonald D.W. 2011. A comparison and critique of different scat-analysis methods for determining carnivore diet. Mammal Review 41, 294-312.

Lecomte N., Ahlstrøm O., Ehrich D., Fuglei E., Ims R.A. \& Yoccoz N.G. 2011. Intrapopulation variability shaping isotope discrimination and turnover: experimental evidence in Arctic foxes. PLoS One 6, e21357, doi: 10.1371/ journal.pone.0021357.

Lindholm A., Gauthier G. \& Desrochers A. 1994. Effects of hatch date and food supply on gosling growth in Arcticnesting greater snow geese. The Condor 96, 898-908.

Long E.S., Sweitzer R.A., Diefenbach D.R. \& Ben-David M. 2005. Controlling for anthropogenically induced 
atmospheric variation in stable carbon isotope studies. Oecologia 146, 148-156.

Macpherson A.H. 1969. The dynamics of Canadian Arctic fox populations. Canadian Wildlife Service Report Series 8. Ottawa: Department of Indian Affairs and Northern Development.

Meltofte H., Piersma T., Boyd H., McCaffery B., Ganter B., Golovnyk V.V., Graham K., Gratto-Trevor C.L., Morrison R.I.G., Nol E., Rösner H., Schamel D., Schekkerman H., Soloviev M.Y., Tomkovich P.S., Tracy D.M., Tulp I. \& Wennerberg L. 2007. Effects of climate variation on the breeding ecology of Arctic shorebirds. Meddelelser om Grønland BioScience 59. Copenhagen: Danish Polar Center.

Nack R.R. \& Andersen D.E. 2006. Brood movements of Eastern Prairie Population Canada geese: potential influence of light goose abundance. Journal of Wildlife Management 70, 435-442.

Nolet B.A., Bauer S., Feige N., Kokorev Y.I., Popov I.Y. \& Ebbinge B.S. 2013. Faltering lemming cycles reduce productivity and population size of a migratory Arctic goose species. Journal of Animal Ecology 82, 804-813.

North American Bird Banding Program. 2016. Game birds, spring 2016 release. US Geological Survey and Canadian Wildlife Service. Accessed by permit-holder on the internet at https://www.pwrc.usgs.gov/bbl/on on 20 December 2016. Information accessible to non-permit-holders by inquiring at https://www.pwrc.usgs.gov/BBL/homepage/datarequest. $\mathrm{cfm}$

Parnell A.C., Inger R., Bearhop S. \& Jackson A.L. 2010. Source partitioning using stable isotopes: coping with too much variation. PLoS One 5, e9672, doi: 10.1371/ journal.pone.0009672.

Phillips D.L. 2012. Converting isotope values to diet composition: the use of mixing models. Journal of Mammalogy 93, 342-352.

Phillips D.L. \& Gregg J.W. 2003. Source partitioning using stable isotopes: coping with too many sources. Oecologia 136, 261-269.

Phillips D.L., Newsome S.D. \& Gregg J.W. 2005. Combining sources in stable isotope mixing models: alternative methods. Oecologia 144, 520-527.

R Development Core Team 2011. R: a language and environment for statistical computing. Vienna: R Foundation for Statistical Computing.

Reiter M.E. \& Andersen D.E. 2008. Trends in abundance of collared lemmings near Cape Churchill, Manitoba, Canada. Journal of Mammalogy 89, 138-144.
Reiter M.E. \& Andersen D.E. 2011. Arctic foxes, lemmings, and Canada goose nest survival at Cape Churchill, Manitoba. Wilson Journal of Ornithology 123, 266-276.

Roth J.D. 2002. Temporal variability in Arctic fox diet as reflected in stable-carbon isotopes: the importance of sea ice. Oecologia 133, 70-77.

Roth J.D. 2003. Variability in marine resources affects Arctic fox population dynamics. Journal of Animal Ecology 72, 668-676.

Samelius G. \& Alisauskas R.T. 2000. Foraging patterns of Arctic foxes at a large Arctic goose colony. Arctic 53, 279-288.

Samelius G., Alisauskas R.T., Hobson K.A. \& Lariviére S. 2007. Prolonging the Arctic pulse: long-term exploitation of cached eggs by Arctic foxes when lemmings are scarce. Journal of Animal Ecology 76, 873-880.

Samelius G., Alisauskas R.T. \& Larivière S. 2011. Seasonal pulses of migratory prey and annual variation in small mammal abundance affect abundance and reproduction by Arctic foxes. Polar Biology 34, 1475-1484.

Scott P.A. \& Hansell R.I.C. 1989. The lemming community on the lichen-heath tundra at Churchill, Manitoba. Canadian Field-Naturalist 103, 358-362.

Skinner W.R., Jefferies R.L., Carleton T.J., Rockwell R.F. \& Abraham K.F. 1998. Prediction of reproductive success and failure in lesser snow geese based on early season climatic variables. Global Change Biology 4, 3-16.

Stickney A. 1991. Seasonal patterns of prey availability and the foraging behavior of Arctic foxes (Alopex lagopus) in a waterfowl nesting area. Canadian Journal of Zoology 69, 2853-2859.

Tannerfeldt M. \& Angerbjörn A. 1998. Fluctuating resources and the evolution of litter size in the Arctic fox. Oikos 83, 545-559.

Tarroux A., Berteaux D. \& Bêty J. 2010. Northern nomads: ability for extensive movements in adult Arctic foxes. Polar Biology 33, 1021-1026.

Tarroux A., Bêty J., Gauthier G. \& Berteaux D. 2012. The marine side of a terrestrial carnivore: intra-population variation in use of allochthonous resources by Arctic foxes. PLoS One 7, e42427, doi: 10.1371/journal. pone.0042427.

Tieszen L.L., Boutton T.W., Tesdahl K.G. \& Slade N.A. 1983. Fractionation and turnover of stable carbon isotopes in animal tissues: implications for $\delta^{13} \mathrm{C}$ analysis of diet. Oecologia 57, 32-37.

White T.C.R. 1978. The importance of a relative shortage of food in animal ecology. Oecologia 33, 71-86. 